\title{
Fibroepithelial Polyp
}

National Cancer Institute

\section{Source}

National Cancer Institute. Fibroepithelial Polyp. NCI Thesaurus. Code C3337.

A polypoid lesion composed of fibrous tissue and epithelium. Representative examples

include skin tag, anal fibroepithelial polyp, and ging ival fibroepithelial polyp. 